\title{
Effects of Sparassis crispa in Medical Therapeutics: A Systematic Review and Meta-Analysis of Randomized Controlled Trials
}

\author{
Le Thi Nhu Ngoc ${ }^{1}$, You-Kwan $\mathrm{Oh}^{2}$, Young-Jong Lee ${ }^{3, *}$ and Young-Chul Lee ${ }^{1, * \mathbb{C}}$ \\ 1 Department of BioNano Technology, Gachon University, 1342 Seongnam-Daero, Sujeong-Gu, Seongnam-Si, \\ Gyeonggi-do 13120, Korea; nhungocle92@gmail.com \\ 2 School of Chemical and Biomolecular Engineering, Pusan National University, 2 Busandaehak-ro, \\ Geumjeong-Gu, Busan 46241, Korea; youkwan@pusan.ac.kr \\ 3 Department of Herbology, College of Korean Medicine, Gachon University, 1342 Seongnam-Daero, \\ Sujeong-Gu, Seongnam-Si, Gyeonggi-do 13120, Korea \\ * Correspondence: garak@gachon.ac.kr (Y.-J.L.); dreamdbs@gachon.ac.kr (Y.-C.L.); \\ Tel.: +82-31-750-5415 (Y.-J.L.); +82-31-750-8751 (Y.-C.L.); \\ Fax: +82-31-750-5416 (Y.-J.L.); +82-31-750-4748 (Y.-C.L.)
}

Received: 31 March 2018; Accepted: 9 May 2018; Published: 16 May 2018

\begin{abstract}
In this study, we investigated the therapeutic potential and medical applications of Sparassis crispa (S. crispa) by conducting a systematic review of the existing literature and performing a meta-analysis. The original efficacy treatment of the mushroom extract is considered primarily and searched in electronic databases. A total of 623 articles were assessed, 33 randomized controlled experiments were included after the manual screening, and some papers, review articles, or editorials that did not contain data were excluded. A comparative standard means difference (SMD) and a funnel plot between control and S. crispa groups were used as parameters to demonstrate the beneficial effects of S. crispa for diabetes and cancer treatment, as well as anti-inflammatory, anti-fungal and antioxidant activities. The meta-analysis was carried out using Review Manager 5.1 software. Although for therapeutic diabetes there was heterogeneity in the subgroup analysis $\left(\mathrm{I}^{2}=91.9 \%\right)$, the overall results showed statistically significant SMDs in major symptoms that decreased serum insulin levels $\left(\mathrm{SMD}=1.92,95 \% \mathrm{CI}(1.10,2.75), \mathrm{I}^{2}=0 \%\right)$, wound rates $(\mathrm{SMD}=3.55(2.56,4.54)$, $\left.\mathrm{I}^{2}=40 \%\right)$ and contributions to an increase in nutrient intake content (SMD $=0.32(-0.15,0.78)$, $\mathrm{I}^{2}=0 \%$ ). Simultaneously, the study confirmed the utility of $S$. crispa treatment in terms of not only anti-cancer activity (reduction of tumor activity and survival of cancer cells $\mathrm{I}^{2}=42$ and $34 \%$, respectively) but also anti-inflammatory, anti-fungal and antioxidant activities $\left(\mathrm{I}^{2}=50,44\right.$, and $10 \%$, respectively). Our findings suggest that $S$. crispa extracts are useful for prevention and treatment of human diseases and might be the best candidates for future medicines.
\end{abstract}

Keywords: Sparassis crispa; diabetes treatment; cancer therapeutic; anti-inflammatory; anti-fungal; antioxidant activity; meta-analysis

\section{Introduction}

Medical mushrooms have been approved as cures in traditional East Asian therapies [1,2]. Scientists around the world have verified the unique properties of compounds extracted from mushrooms in the prevention and treatment of cancer and other chronic diseases [3].

Sparassis crispa (S. crispa) is a species of fungus belonging to the genus Sparassis, known as Cauliflower mushroom or Sparassis latifolia; also called by other names such as Hanabiratake in Japanese [2-4]. S. crispa is not only an edible mushroom but also a well-known medicinal 
mushroom that has many medical applications [3,5] (e.g., anti-tumor and anti-carcinogenic properties; anti-inflammatory, antiviral, anti-hypertensive, anti-allergic, anti-diabetic activities, and cytokine induction [1-3,6,7]). Recently, this mushroom has been widely utilized in Japan and Korea [3,7,8].

S. crispa contains highly active biological and pharmacological ingredients (e.g., $\beta$-glucan, anti-fungal compounds (sparassol, methyl-2,4-dihydroxy-6-methylbenzoate, and methyldihydroxymethoxy-methylbenzoate), ergosterol peroxides, and benzoate derivatives) that are useful in the treatment of human disease [3,5,9-11]. In particular, $\beta$-glucan can prevent and heal common health problems such as diabetes, cancer, wound healing, as well as immune system and cytokine induction $[1,6,12-15]$. In addition, phenolic compounds, anti-fungal substances, and other S. crispa extracts may be used as anti-oxidant or anti-fungal agents [3,16-19].

Several studies have indicated, through tests on either mice or human cell lines, that S. crispa is a potential natural source of medicinal ingredients that can contribute to the limitations and even prevention of human disease (e.g., cancer, allergies, and especially diabetic disease) $[12,13,19,20]$ However, in individual studies, scientists have not focused on the overall assessments of the benefits of S. crispa in human health as a systematic review. Thus, this study reviewed randomized and controlled trials, also conducted a systematic review and meta-analysis to evaluate the statistically significant benefits of $S$. crispa in therapeutic approaches.

\section{Results}

\subsection{Characteristics of Included Studies}

Figure 1 shows the flow of candidate and eligible articles. Our searches in databases yielded a total of 623 different publications whose titles and abstracts were screened and 270 were considered relevant only by title and abstract. After reviewing these 270 full-text articles on the efficiency of S. crispa extracts for human-disease treatment, thirty-three articles were considered eligible and, therefore, included in the quantitative meta-analysis. One of those articles was written in Japanese [21], seven in Korean [19,22-27], and the remaining in English. Among them, some studies demonstrated more than two healing effects of the mushroom [7,26,28-30]. Simultaneously, the anti-diabetic, anti-tumor, anti-inflammatory, anti-fungal, and antioxidant activities of S. crispa were reported in seven $[6,12,14,28-31]$, nine-teen $[7,13,15,21,23,24,26,28,30,32-41]$, four $[7,22,30,42]$, three $[19,29,43]$, and six $[8,25-27,44,45]$ studies, respectively.

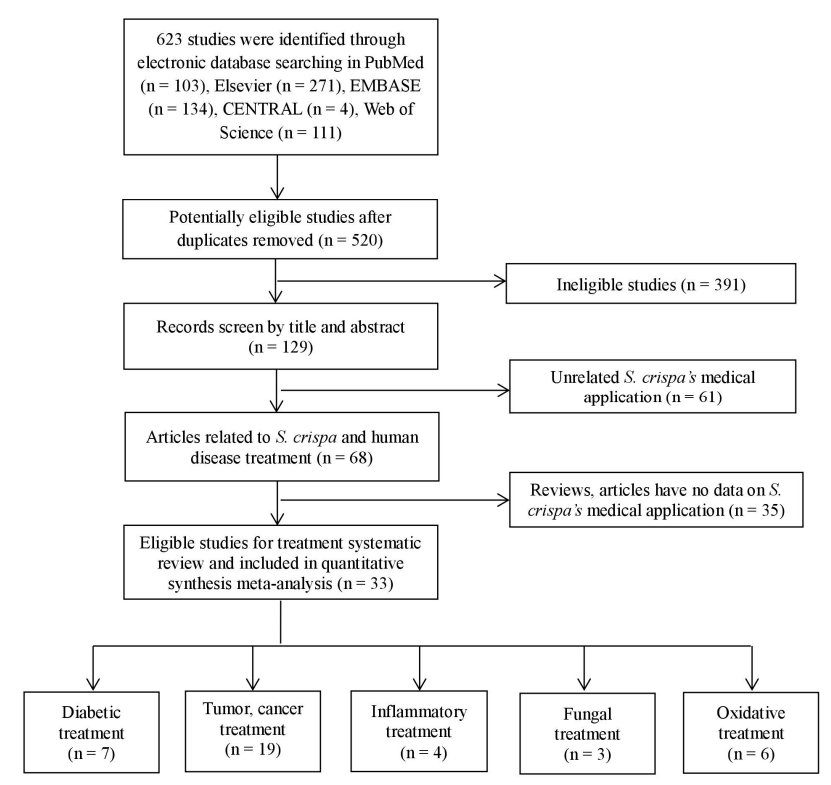

Figure 1. Systematic screening stages of the literature review. 
All these thirty-three studies estimated the S. crispa benefits based on rats, diabetic mice, and cancer cell test (see Table 1), and provided raw data for a standardized mean difference (SMD) estimation.

Table 1. Summary of the characteristics of the studies included in this work.

\begin{tabular}{|c|c|c|c|c|c|c|}
\hline Reference & $\begin{array}{c}\text { Characteristic of } \\
\text { Object }\end{array}$ & $\begin{array}{c}\text { S. crispa } \\
\text { Extract } \\
\text { Compound }\end{array}$ & $\begin{array}{c}\text { Medical } \\
\text { Therapeutic }\end{array}$ & $n$ & Dosage & Location \\
\hline [6] Kwon et al., 2009 & Mice & $\beta$-glucan & Anti-diabetic & 10 & $\begin{array}{c}100 \mu \mathrm{g} / \mathrm{mL} \\
\beta \text {-glucan }\end{array}$ & Korea \\
\hline [32] Kim et al., 2010 & Dendritic cell & $\beta$-glucan & Anti-tumor & 3 & $\begin{array}{c}100 \mu \mathrm{g} / \mathrm{mL} \\
\beta \text {-glucan }\end{array}$ & Korea \\
\hline $\begin{array}{l}\text { [31] Yoshitomi } \\
\text { et al., } 2011\end{array}$ & Mice & $\beta$-glucan & Anti-diabetic & 8 & $\begin{array}{c}100 \mu \mathrm{g} / \mathrm{mL} \\
\beta \text {-glucan }\end{array}$ & Japan \\
\hline [33] Lee et al., 2010 & RAW 264.7 cell & $\beta$-glucan & Anti-tumor & 3 & $\begin{array}{c}250 \mu \mathrm{g} / \mathrm{mL} \\
\beta \text {-glucan }\end{array}$ & Korea \\
\hline [34] Choi et al., 2016 & Human fibrinogen & Wulfase & Anti-tumor & 3 & $\begin{array}{l}200 \mu \mathrm{g} / \mathrm{mL} \\
\text { Wulfase }\end{array}$ & Korea \\
\hline $\begin{array}{l}\text { [15] Harada et al., } \\
2002 a\end{array}$ & $\begin{array}{l}\text { CD } 41 \text { and CD } 81 \\
\text { cell }\end{array}$ & $\beta$-glucan & Anti-tumor & 3 & $\begin{array}{c}200-250 \mu \mathrm{g} / \mathrm{mL} \\
\beta \text {-glucan }\end{array}$ & Japan \\
\hline $\begin{array}{l}\text { [35] Harada et al., } \\
2003\end{array}$ & Mice & $\beta$-glucan & Anti-tumor & 4 & $\begin{array}{c}25 \mu \mathrm{g} / \mathrm{mL} \\
\beta \text {-glucan }\end{array}$ & Japan \\
\hline $\begin{array}{l}\text { [28] Yamamoto } \\
\text { et al., } 2009\end{array}$ & $\begin{array}{c}\text { C57BL/6J } \\
\text { cell/Mice cell line }\end{array}$ & $\beta$-glucan & $\begin{array}{l}\text { Anti-diabetic } \\
\text { Anti-tumor }\end{array}$ & 10 & $\begin{array}{c}160 \mu \mathrm{g} / \mathrm{mL} \\
\beta \text {-glucan }\end{array}$ & Japan \\
\hline $\begin{array}{l}\text { [7] Yoshikama } \\
\text { et al., } 2010\end{array}$ & RAW 264.7 cell & $\begin{array}{l}\text { Phthalide } \\
\text { compounds }\end{array}$ & Anti-tumor & $3-4$ & $\begin{array}{l}100 \mu \mathrm{g} / \mathrm{mL} \\
\text { phthalide } \\
\text { compound }\end{array}$ & Japan \\
\hline $\begin{array}{c}\text { [21] Yamamoto } \\
\text { et al., } 2007\end{array}$ & Sarcoma180 cell & $\begin{array}{l}\text { S. crispa } \\
\text { extract }\end{array}$ & Anti-tumor & 3 & $\begin{array}{c}35 \mu \mathrm{g} / \mathrm{mL} \\
\beta \text {-glucan }\end{array}$ & Japan \\
\hline $\begin{array}{l}\text { [14] Yamamoto } \\
\text { et al., } 2010\end{array}$ & Mice & $\begin{array}{l}\text { S. crispa } \\
\text { extract }\end{array}$ & Anti-diabetic & $6-8$ & $\begin{array}{c}100 \mu \mathrm{g} / \mathrm{mL} \\
\beta \text {-glucan }\end{array}$ & Japan \\
\hline $\begin{array}{l}\text { [29] Jeong } \\
\text { et al., } 2017\end{array}$ & Mice & $\beta$-glucan & $\begin{array}{l}\text { Anti-diabetic } \\
\text { Anti-fungal }\end{array}$ & 12 & $\begin{array}{c}100 \mu \mathrm{g} / \mathrm{mL} \\
\beta \text {-glucan }\end{array}$ & Korea \\
\hline [22] Choi et al., 2013 & RAW 264.7 cell & $\beta$-glucan & Anti-inflammatory & 3 & $\begin{array}{c}200 \mu \mathrm{g} / \mathrm{mL} \\
\beta \text {-glucan }\end{array}$ & Korea \\
\hline [23] Choi et al., 2014 & $\begin{array}{c}\text { A529 cell } \\
\text { HepG2 cell } \\
\text { AGS cell }\end{array}$ & $\beta$-glucan & Anti-tumor & 12 & $\begin{array}{c}250 \mu \mathrm{g} / \mathrm{mL} \\
\beta \text {-glucan }\end{array}$ & Korea \\
\hline [30] Kimura T. 2013 & $\begin{array}{c}\text { Sarcoma } 180 \text { cell } \\
\text { Mice } \\
\text { Colon cancer cell } \\
\text { F3444N/Rat }\end{array}$ & $\beta$-glucan & $\begin{array}{c}\text { Anti-diabetic } \\
\text { Anti-tumor } \\
\text { Anti-inflammatory }\end{array}$ & $3-5$ & $\begin{array}{c}100 \mu \mathrm{g} / \mathrm{mL} \\
\beta \text {-glucan }\end{array}$ & Japan \\
\hline [42] Kim et al., 2012 & Mast cell (HMC-1) & $\begin{array}{l}\text { S. crispa } \\
\text { extract }\end{array}$ & Anti-inflammatory & 3 & $\begin{array}{c}200 \mu \mathrm{g} / \mathrm{mL} \\
\text { S. crispa extract }\end{array}$ & Korea \\
\hline [36] Hu et al., 2016 & PC12 cell & $\beta$-glucan & Anti-tumor & 6 & $\begin{array}{c}250 \mu \mathrm{g} / \mathrm{mL} \\
\beta \text {-glucan }\end{array}$ & China \\
\hline $\begin{array}{l}\text { [44] Puttaraju } \\
\text { et al., } 2006\end{array}$ & Mice & $\begin{array}{l}\text { S. crispa } \\
\text { extract }\end{array}$ & Antioxidant & 3 & $\begin{array}{c}30 \mu \mathrm{g} / \mathrm{mL} \\
\beta \text {-glucan }\end{array}$ & India \\
\hline [8] Kim et al., 2008 & Mice or cell & $\begin{array}{l}\text { S. crispa } \\
\text { extract }\end{array}$ & Antioxidant & 3 & $\begin{array}{c}100 \mu \mathrm{g} / \mathrm{mL} \\
\text { S. crispa extract }\end{array}$ & Korea \\
\hline $\begin{array}{c}\text { [43] Woodward } \\
\text { et al., } 1992\end{array}$ & Botrytis cinerea & $\begin{array}{l}\text { Antibiotic } \\
\text { compounds }\end{array}$ & Anti-fungal & 10 & $\begin{array}{l}100 \mu \mathrm{g} / \mathrm{mL} \\
\text { antibiotic } \\
\text { compound }\end{array}$ & $\begin{array}{l}\text { United } \\
\text { Kingdom }\end{array}$ \\
\hline $\begin{array}{l}\text { [13] Ohno } \\
\text { et al., } 2000\end{array}$ & Mice & $\begin{array}{l}\text { S. crispa } \\
\text { extract }\end{array}$ & Anti-tumor & 10 & $\begin{array}{c}250 \mu \mathrm{g} / \mathrm{mL} \\
\text { S. crispa extract }\end{array}$ & Japan \\
\hline $\begin{array}{l}\text { [12] Yamamoto } \\
\text { et al., } 2014\end{array}$ & Mice & $\beta$-glucan & Anti-diabetic & $10-18$ & $\begin{array}{c}250 \mu \mathrm{g} / \mathrm{mL} \\
\beta \text {-glucan }\end{array}$ & Japan \\
\hline [19] Lee et al., 2013a & Soybean & $\begin{array}{l}\text { S. crispa } \\
\text { extract }\end{array}$ & Anti-fungal & 3 & $\begin{array}{c}125 \mu \mathrm{g} / \mathrm{mL} \\
\text { S. crispa extract }\end{array}$ & Korea \\
\hline [24] Kim et al., 2013 & Raw 264.7 cell & $\beta$-glucan & Anti-tumor & 5 & $\begin{array}{c}100 \mu \mathrm{g} / \mathrm{mL} \\
\beta \text {-glucan }\end{array}$ & Korea \\
\hline $\begin{array}{l}\text { [37] Harada } \\
\text { et al., 2002b }\end{array}$ & Mice & $\beta$-glucan & Anti-tumor & 5 & $\begin{array}{c}100 \mu \mathrm{g} / \mathrm{mL} \\
\beta \text {-glucan }\end{array}$ & Japan \\
\hline
\end{tabular}


Table 1. Cont.

\begin{tabular}{ccccccc}
\hline Reference & $\begin{array}{c}\text { Characteristic of } \\
\text { Object }\end{array}$ & $\begin{array}{c}\text { S.crispa } \\
\text { Extract } \\
\text { Compound }\end{array}$ & $\begin{array}{c}\text { Medical } \\
\text { Therapeutic }\end{array}$ & $n$ & Dosage & Location \\
\hline $\begin{array}{c}\text { [38] Harada } \\
\text { et al., 2004 }\end{array}$ & Mice & $\beta$-glucan & Anti-tumor & 3 & $\begin{array}{c}100 \mu \mathrm{g} / \mathrm{mL} \\
\beta \text {-glucan }\end{array}$ & Japan \\
\hline $\begin{array}{c}\text { [39] Harada } \\
\text { et al., 2006 }\end{array}$ & Mice & $\beta$-glucan & Anti-tumor & 3 & $\begin{array}{c}100 \mu \mathrm{g} / \mathrm{mL} \\
\beta \text {-glucan }\end{array}$ & Japan \\
\hline $\begin{array}{c}\text { [40] Nameda } \\
\text { et al., 2003 }\end{array}$ & Mice & $\beta$-glucan & Anti-tumor & 3 & $\begin{array}{c}50 \mu \mathrm{\mu g} / \mathrm{mL} \\
\beta \text {-glucan }\end{array}$ & Japan \\
\hline [41] Yao et al., 2008 & Mice & $\beta$-glucan & Anti-tumor & 10 & $\begin{array}{c}120 \mu \mathrm{g} / \mathrm{mL} \\
\beta \text {-glucan }\end{array}$ & China \\
\hline [25] Lee et al., 2016a & Soybean & $\beta$-glucan & Antioxidant & 3 & $\begin{array}{c}200 \mu \mathrm{g} / \mathrm{mL} \\
\beta \text {-glucan }\end{array}$ & Korea \\
\hline [26] Park et al., 2016 & Mice & $\begin{array}{c}\text { S.crispa } \\
\text { extract }\end{array}$ & Antioxidant & 6 & $\begin{array}{c}200 \mu \mathrm{g} / \mathrm{mL} \mathrm{S.} \\
\text { crispa extract }\end{array}$ & Korea \\
\hline [27] Lee et al., 2016b & Cell & $\begin{array}{c}\text { S. crispa } \\
\text { extract }\end{array}$ & Antioxidant & 3 & $\begin{array}{c}50 \mu \mathrm{\mu g} / \mathrm{mL} \\
\beta \text {-glucan }\end{array}$ & Korea \\
\hline [45] Lee et al., 2013b & Mice & $\begin{array}{c}\text { Phenolic } \\
\text { compounds }\end{array}$ & Antioxidant & 3 & $\begin{array}{c}200 \mu \mathrm{m} / \mathrm{mL} \\
\mathrm{phenolic} \\
\text { compounds }\end{array}$ & Korea \\
\hline
\end{tabular}

\subsection{Risk of Bias}

To explore the validity of eligible randomized studies, the quality of bias assessment of the included studies was determined by evaluating the bias of the random sequence generation, allocation concealment, selective reporting, blinding of participants and outcome assessment, and incomplete outcome data based on three levels following the Cochrane guideline (low and high risk of bias that may indicate either lack of information or uncertainty over the potential for bias) [46]. According to Table 2 and Figure 2, almost all criteria showed a low risk of bias, especially in studies where homogeneity in the random sequence generation criteria was used. Resulting in an evident enhanced of the statistical significance of the meta-analysis.

Table 2. Risk of bias rating of each study.

\begin{tabular}{|c|c|c|c|c|c|c|}
\hline Study & $\begin{array}{c}\text { Random } \\
\text { Sequence } \\
\text { Generation }\end{array}$ & $\begin{array}{l}\text { Allocation } \\
\text { Concealment }\end{array}$ & $\begin{array}{l}\text { Selective } \\
\text { Reporting }\end{array}$ & $\begin{array}{l}\text { Blinding of } \\
\text { Participants }\end{array}$ & $\begin{array}{l}\text { Blinding of } \\
\text { Outcome } \\
\text { Assessment }\end{array}$ & $\begin{array}{c}\text { Incomplete } \\
\text { Outcome } \\
\text { Data }\end{array}$ \\
\hline [6] Kwon et al., 2009 & & & & & & \\
\hline [31] Yoshitomi et al., 2011 & & & & & & \\
\hline [33] Lee et al., 2010 & & & & & & \\
\hline $\begin{array}{l}\text { [34] Choi et al., } 2016 \\
\text { [15] Harada et al. 2002a }\end{array}$ & & & & & & \\
\hline [35] Harada et al., 2003 & & & & & & \\
\hline [28] Yamamoto et al., 2009 & & & & & & \\
\hline [7] Yoshikama et al., 2010 & & & & & & \\
\hline [21] Yamamoto et al., 2007 & & & & & & \\
\hline [14] Yamamoto et al., 2010 & & & & & & \\
\hline [29] Jeong et al., 2017 & & & & & & \\
\hline [22] Choi et al., 2013 & & & & & & \\
\hline [23] Choi et al., 2014 & & & & & & \\
\hline [30] Kimura T. 2013 & & & & & & \\
\hline [42] Kim et al., 2012 & & & & & & \\
\hline [36] Hu et al., 2016 & & & & & & \\
\hline [44] Puttaraju et al., 2006 & & & & & & \\
\hline [8] Kim et al., 2008 & & & & & & \\
\hline [43] Woodward et al., 1992 & & & & & & \\
\hline [13] Ohno et al., 2000 & & & & & & \\
\hline [12] Yamamoto et al., 2014 & & & & & & \\
\hline [19] Lee et al., 2013a & & & & & & \\
\hline
\end{tabular}


Table 2. Cont.

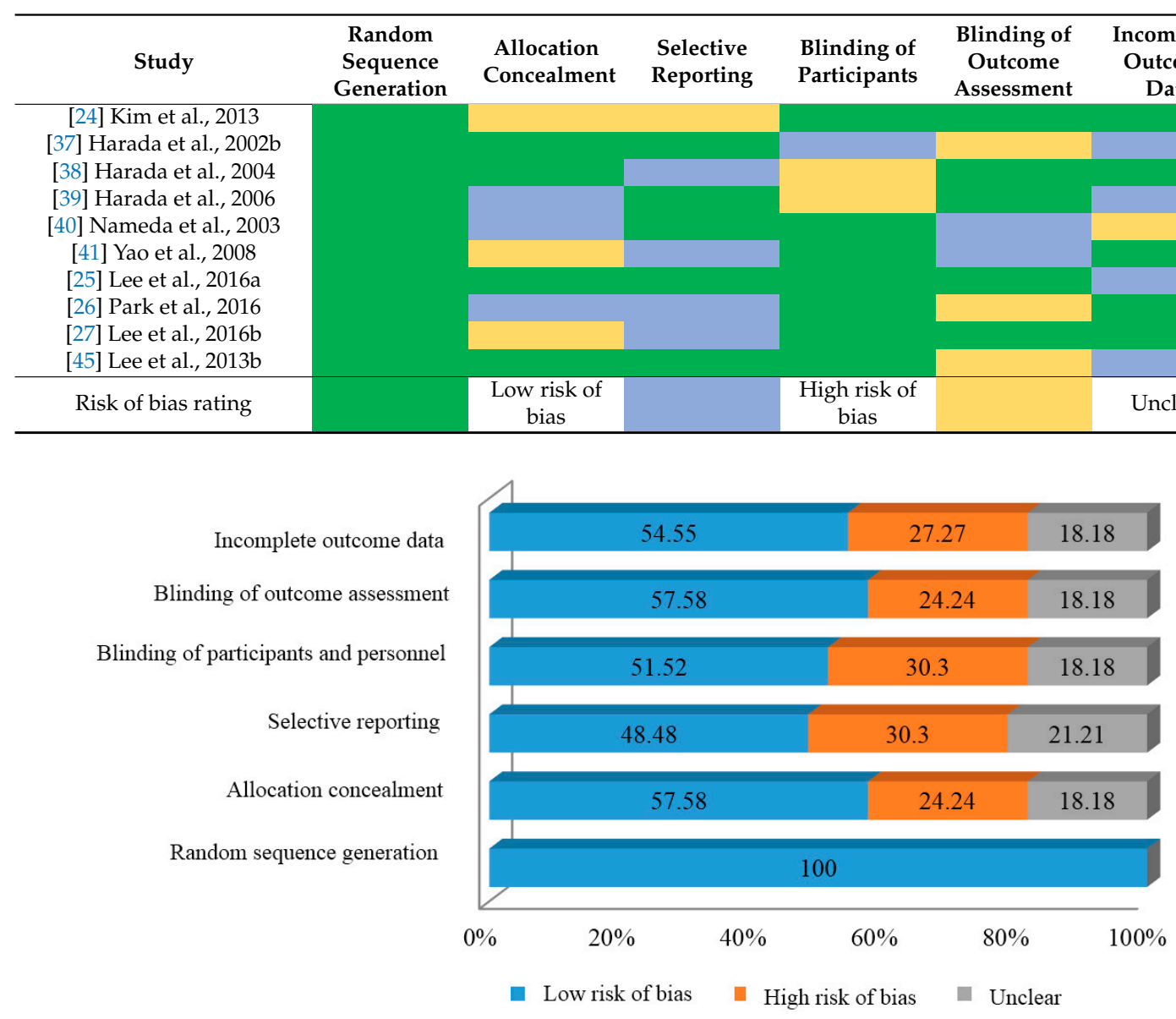

Figure 2. Risk of bias in individual studies graph.

\subsection{Diabetes Treatment}

Anti-diabetic activity was evaluated by seven studies [6,12,14,28-31] (Figure 3 and Table 3). Most of the assays were performed in diabetic rat and mouse cells, and the treatment was assessed in five aspects: serum glucose levels $(\mathrm{mg} / \mathrm{dL})$, serum insulin levels $(\mathrm{mg} / \mathrm{dL})$, nutrition intake $(\mathrm{mL})$, body weight ( $\mathrm{g}$ ) of mice or tissues before and after treatment, as well as wound healing ability (\%). In addition, some individual studies have identified and demonstrated the beneficial effects of $S$. crispa in several healing aspects, so they were evaluated in various separate analyses. For instance, Yamamoto et al. showed that $S$. crispa could prevent human diabetes by reducing serum glucose levels, insulin levels, and increasing the body weight of diabetic mice [14]. In addition, Jeong et al. indicated the capability of $S$. crispa in four aspects including serum glucose and insulin levels, nutrition intake, and body weight [29]. 


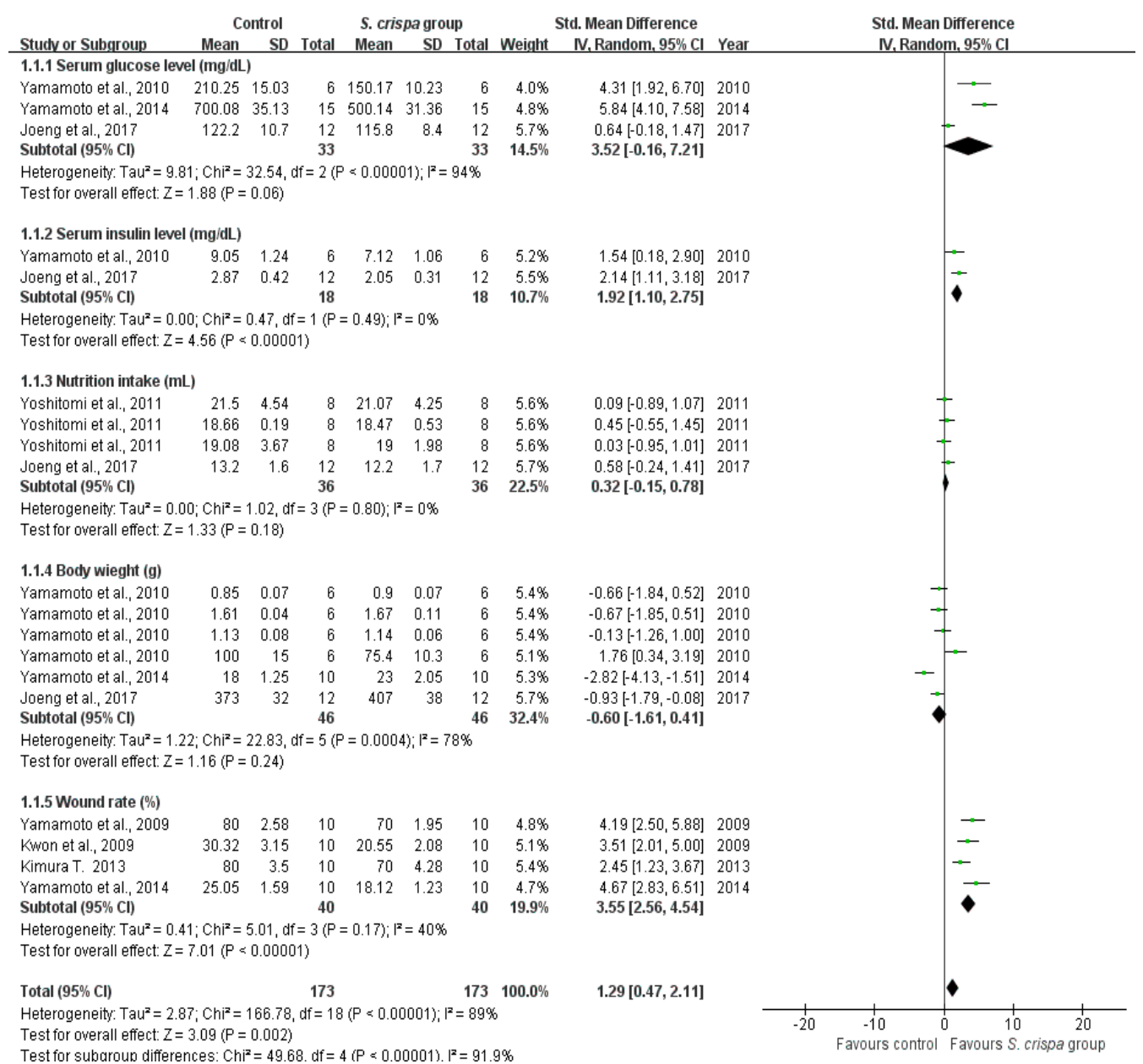

Figure 3. Comparison of diabetic symptoms between control and S. crispa groups. (--): SMD of individual studies; $(\bullet)$ : summary SMDs of the comparison.

Table 3. Summary of standardized mean difference (SMD) comparison between control and S. crispa groups.

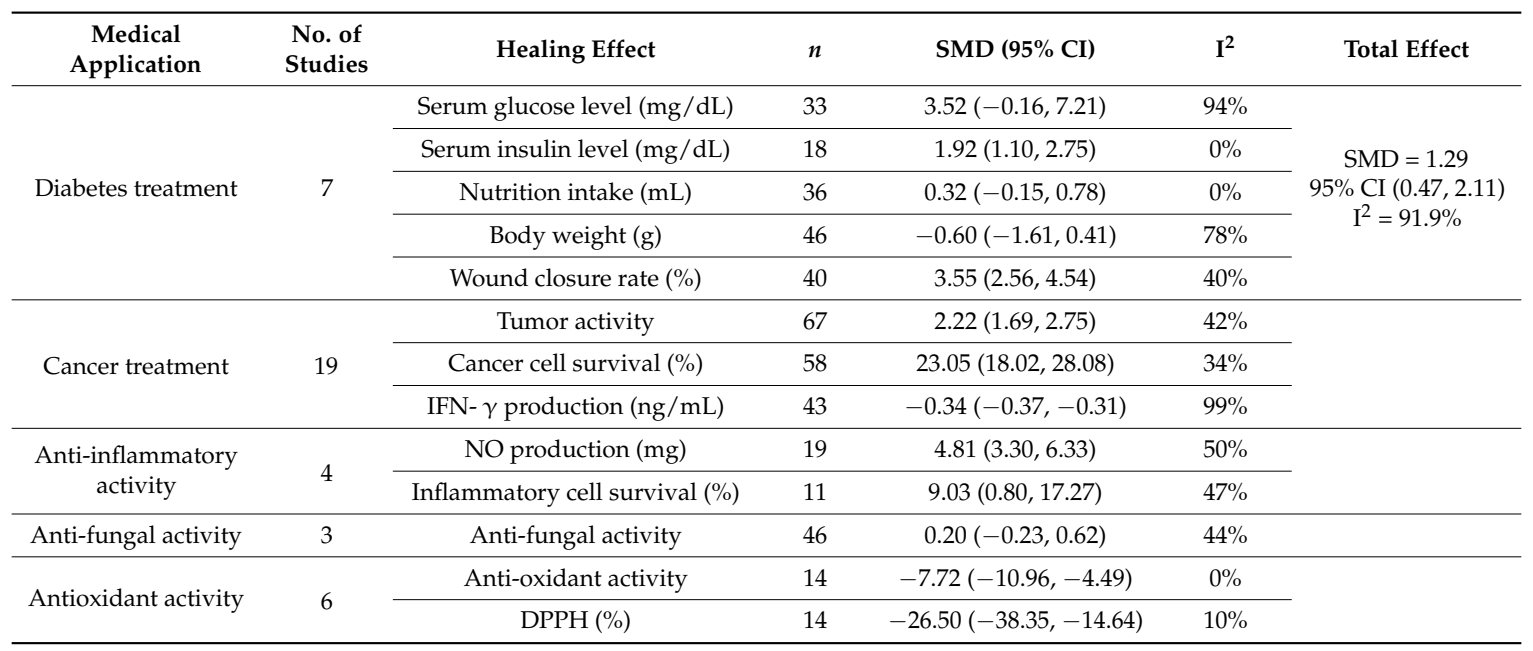

A subgroup analysis was conducted to quantify the effect of S. crispa in all therapeutic approaches comparing to the control group. Anti-diabetic activity was significantly higher in the S. crispa group than in the control group, and results showed a significant effect of $S$. crispa in the treatment $(\mathrm{SMD}=1.29,95 \%$ confidence interval $(\mathrm{CI})(0.47,2.11), p<0.00001)$, although a heterogeneity was 
observed in the subgroup analysis (heterogeneity $\mathrm{X}^{2}=50.24, p<0.00001, \mathrm{I}^{2}=91.9 \%$ ). However, when was considered each aspect of the diabetes treatment, the comparison between serum insulin levels and wound healing rates showed significant homogeneities in all reported symptoms and presented a large SMD between the two groups ( $\left.\mathrm{SMD}=1.92,95 \% \mathrm{CI}(1.10,2.75), \mathrm{I}^{2}=0 \%\right)$ and $\left(\mathrm{SMD}=3.55,95 \% \mathrm{CI}(2.56,4.54), \mathrm{I}^{2}=40 \%\right)$, respectively). Neither nutrition intakes showed heterogeneity SMD (SMD $=0.32,95 \%$ CI $\left.(-0.15,0.78), \mathrm{I}^{2}=0 \%\right)$. Nevertheless, serum glucose levels and body weights of rats showed high heterogeneity $\left(\mathrm{I}^{2}=94 \%\right.$ and $\mathrm{I}^{2}=78 \%$, respectively).

\subsection{Cancer Treatment}

From nine-teen studies $[7,13,15,21,23,24,26,28,30,32-41]$, seven reported an anti-tumor activity, five showed an inhibition of cancer cell viability, and nine indicated IFN- $\gamma$ induction of S. crispa extracts. On the other hand, there are several reports which showed appropriate data in many respects [3,7]. In addition, when considering the capability of healing, researchers performed experiments to describe the effect of $S$. crispa extract in various types of cells $[3,15,23]$ or to determine the therapeutic potential of different $S$. crispa extracts on a cell type [7]. Therefore, these studies have been evaluated and appeared multiple times in a comparison of this analysis. An individual analysis was applied to two groups for each of those aspects, showing significant inter-group differences (see Figures 4-6).

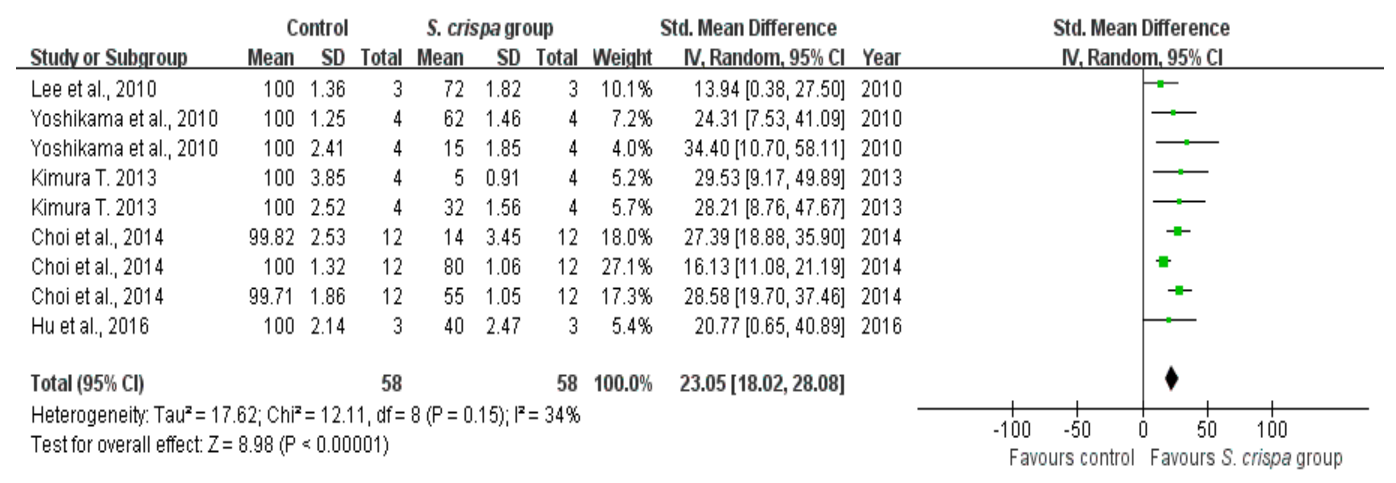

Figure 4. Comparison of the survival of cancer cells between control and S. crispa groups. (- -$)$ : SMD of individual studies; $(\bullet)$ : summary SMDs of the comparison.

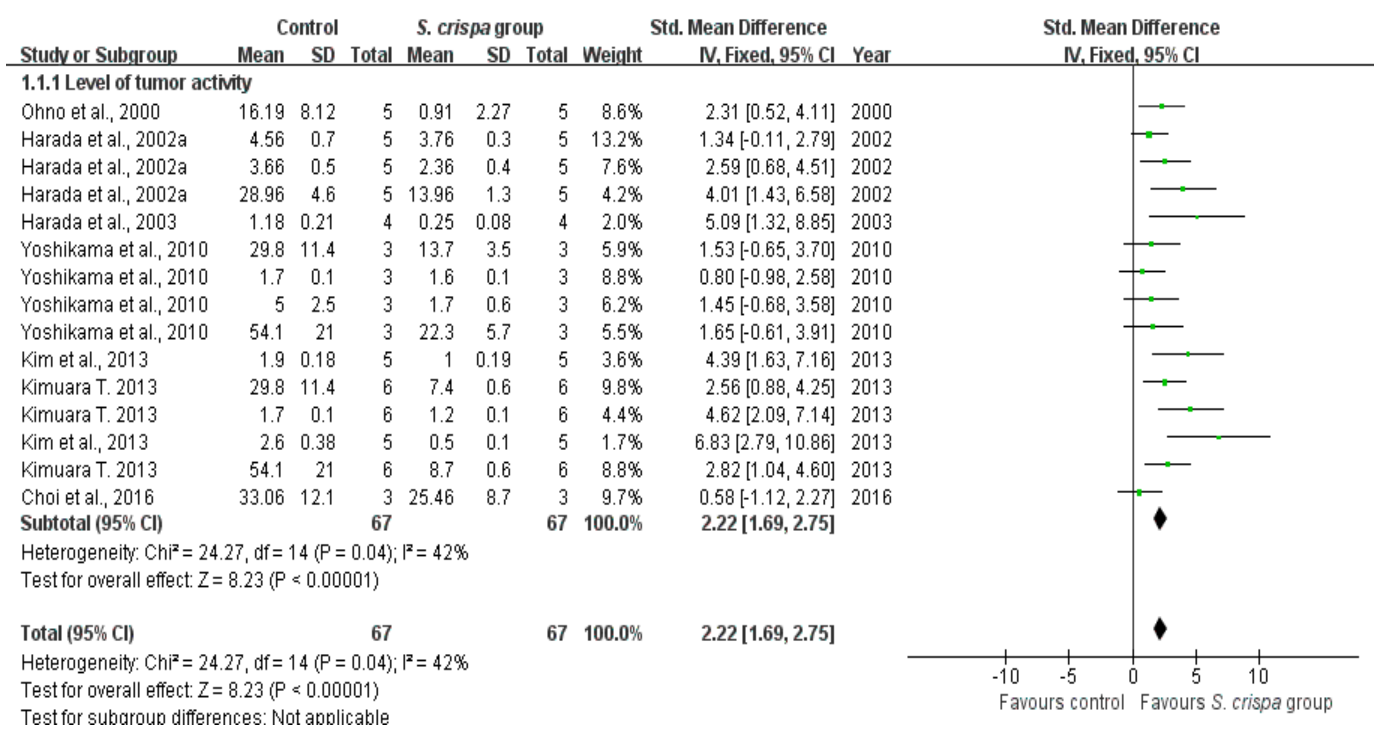

Figure 5. Comparison of levels of tumor activity between control and S. crispa groups. (-- - ): SMD of individual studies; $(\bullet)$ : summary SMDs of the comparison. 


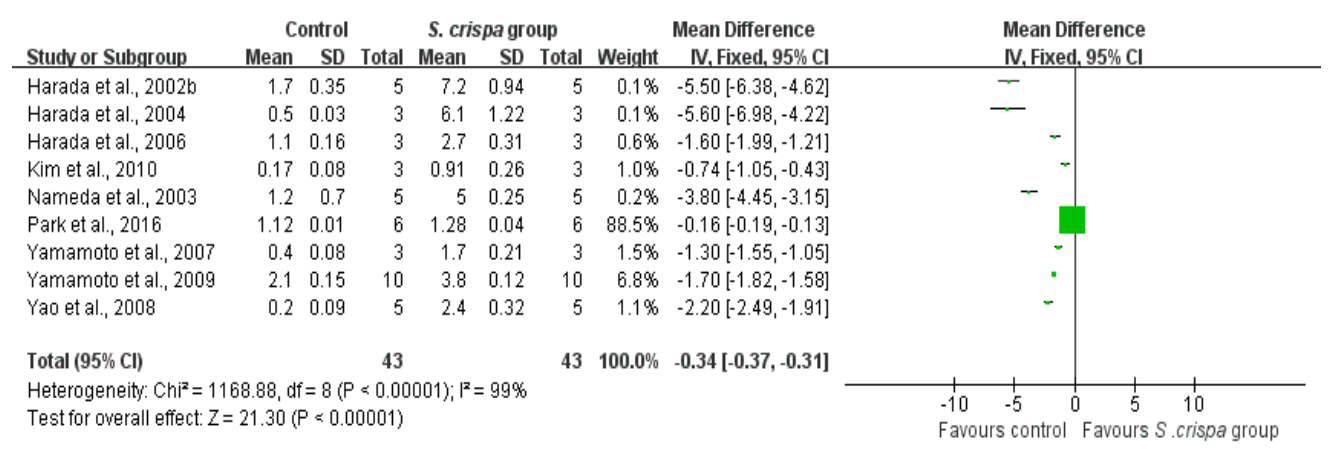

Figure 6. Comparison of the IFN- $\gamma$ production potential between control and S. crispa groups. (- - ): SMD of individual studies; $(\bullet)$ : summary SMDs of the comparison.

A comparison between the control and S. crispa group showed a lower tumor cell activity $(\mathrm{SMD}=2.22,95 \% \mathrm{CI}(1.69,2.75), p<0.00001)$; that reduction was relevant to the homogeneity in seven studie $[7,13,15,24,30,34,35]\left(X^{2}=24.27, \mathrm{I}^{2}=42 \%\right)$. Additionally, the heterogeneity was not significant for the survival of cancer cells $\left(X^{2}=12.11, \mathrm{I}^{2}=34 \%\right)$ in five studies $[7,23,30,33,36]$, resulting in a dramatical decrease in the cancer cell viability after exposure to S. crispa (SMD $=21.36,95 \% \mathrm{CI}$ $(17.91,24.81), p<0.00001)$. The SMD between these two groups did not show a significant of the IFN- $\gamma$ induction aspect $\left(\mathrm{SMD}=-0.34,95 \% \mathrm{CI}(-0.37,-0.31), \mathrm{X}^{2}=1168.88, \mathrm{I}^{2}=99 \%\right)$.

\subsection{Anti-Inflammatory Activity}

Data about anti-inflammatory activities of $S$. crispa extracts were reported in four studies $[7,22,30,42]$. According to SMDs (Figures 7 and 8, and Table 3), those results demonstrated that S. crispa reduced inflammatory cells survival $\left(\mathrm{SMD}=9.03,95 \% \mathrm{CI}(0.80,17.27), \mathrm{X}^{2}=3.74, \mathrm{I}^{2}=47 \%\right)$. The heterogeneity did not exist when was compared the NO production potential between control and S. crispa groups, with a large effect $\left(\mathrm{SMD}=4.81,95 \% \mathrm{CI}(3.30,6.33), \mathrm{X}^{2}=4.01, \mathrm{I}^{2}=50 \%\right)$.

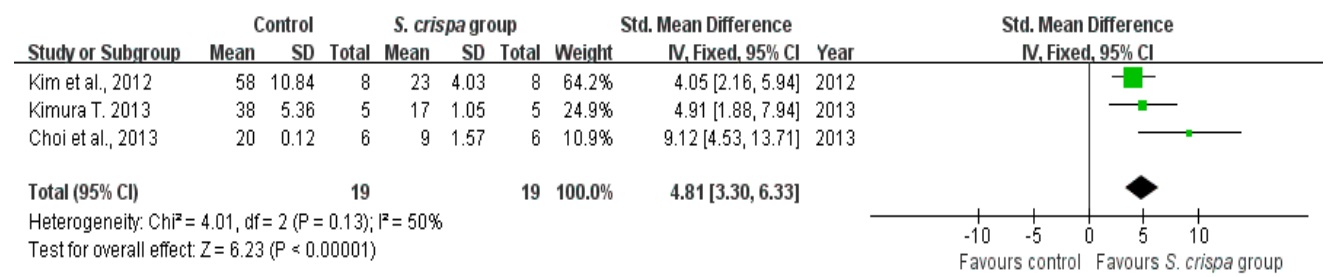

Figure 7. Comparison of NO production potential between control and S. crispa groups. (-E-): SMD of individual studies; $(\bullet)$ : summary SMDs of the comparison.

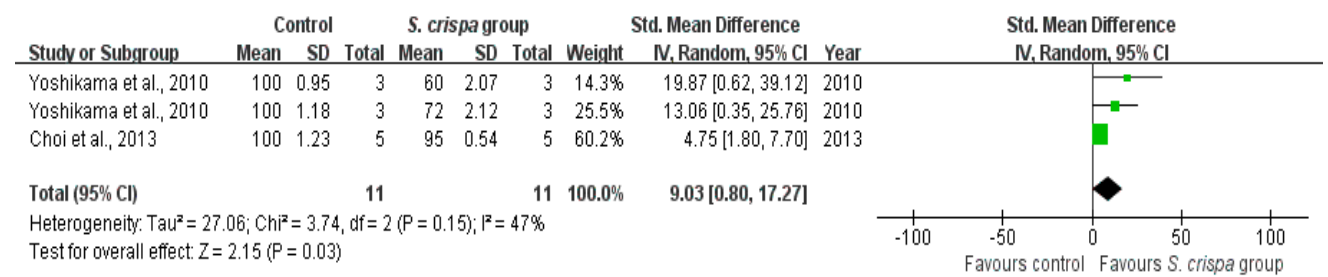

Figure 8. Comparison of inflammatory cells survival between control and S. crispa groups. (- -$)$ : SMD of individual studies; $(\bullet)$ : summary SMDs of the comparison.

\subsection{Anti-Fungal Activity}

Anti-fungal compounds are produced by S. crispa in cultures and in wood decomposed naturally, as reported in three studies $[19,29,43]$. According to these studies, results of the meta-analysis (Figure 9) 
there was a favorable effect in the S. crispa group; the numbers of bacteria and fungi were reduced in the treatment group compared with the control group. A significant difference was found between these two groups (SMD $=0.20,95 \% \mathrm{CI}(-0.23,0.62), \mathrm{X}^{2}=8.86, \mathrm{I}^{2}=44 \%<50 \%$ ).

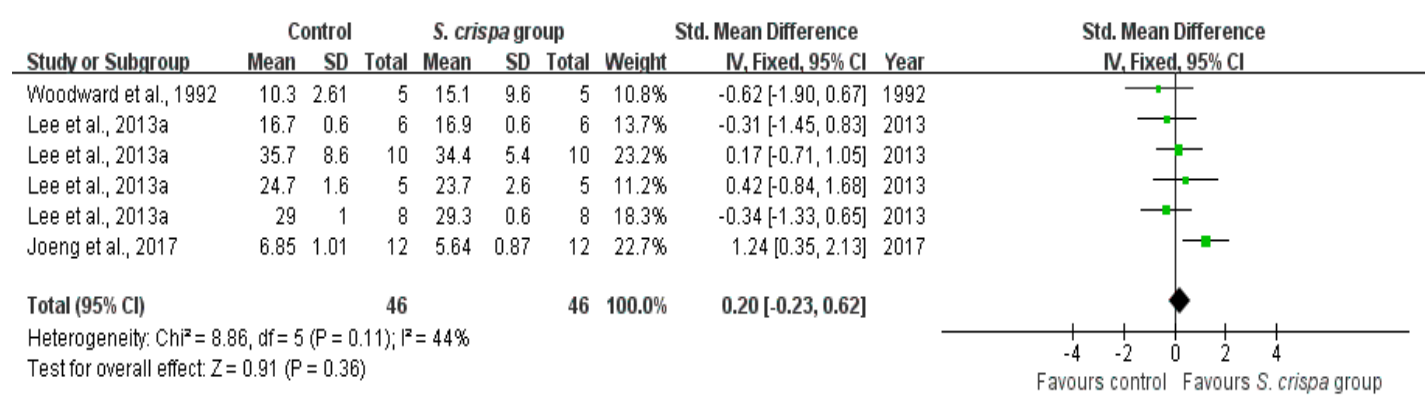

Figure 9. Comparison of the anti-fungal activity between control and S. crispa groups. (-- - ): SMD of individual studies; $(\bullet)$ : summary SMDs of the comparison.

\subsection{Antioxidant Activity}

According to six studies [8,25-27,44,45], the antioxidant activity was performed through DPPH (2, 2-diphenyl-1-picrylhydrazyl radical scavenging activity and the oxidative-inhibitory capacity of phenolic compounds derived from S. crispa. In both cases, the S. crispa group reported a higher level of oxidative protection than the control group, with evidence of improving antioxidant activity (Figures 10 and 11). The inhibitory activity indicated a significant homogeneity with $\mathrm{I}^{2}=0 \%$ and $\mathrm{X}^{2}=1.10(\mathrm{SMD}=-7.72,95 \% \mathrm{CI}(-10.96,-4.49), p<0.00001)$, while the DPPH activity showed a very high statistical significance in the inter-group comparison of four relevant studies (SMD $=-26.50$, $95 \%$ CI $\left.(-38.35,-14.64), p<0.00001, \mathrm{X}^{2}=3.32, \mathrm{I}^{2}=10 \%\right)$.

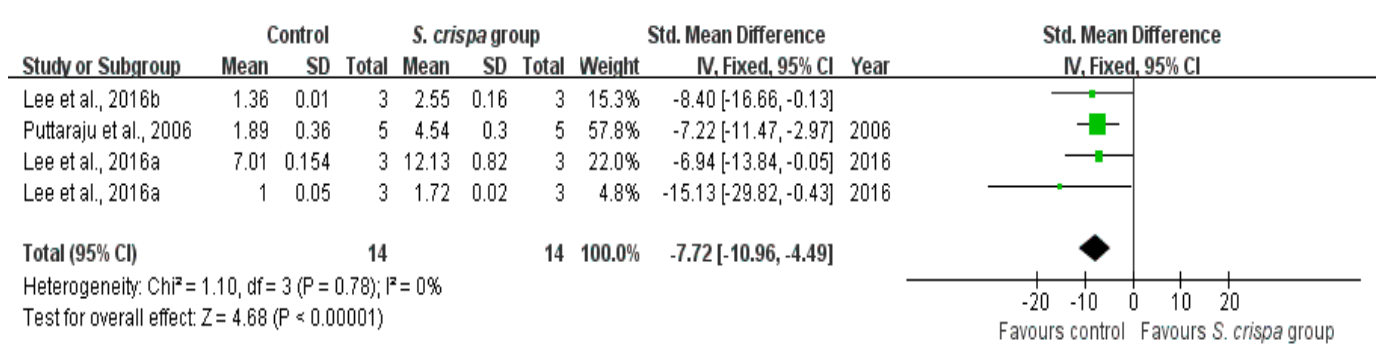

Figure 10. Comparison of oxidative inhibitory capacity between control and S. crispa groups. (- -$)$ : SMD of individual studies; $(\bullet)$ : summary SMDs of the comparison.

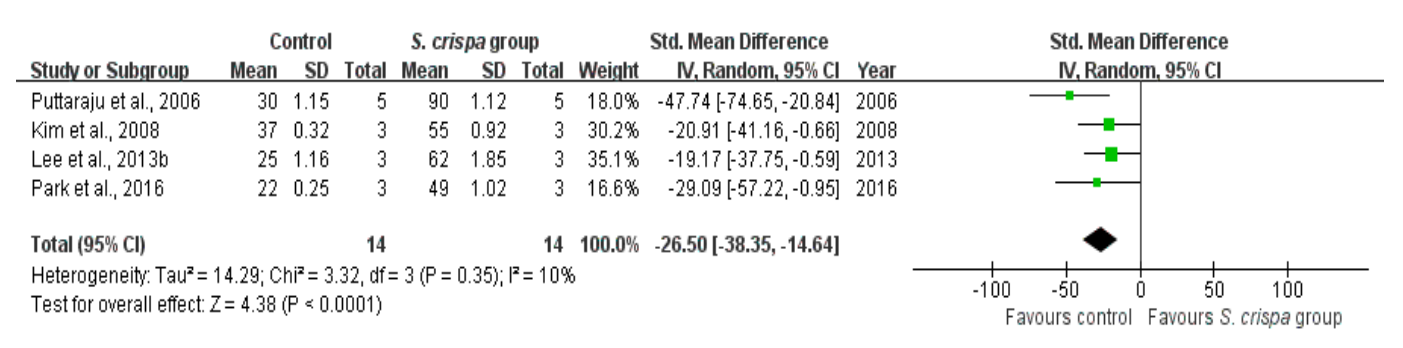

Figure 11. Comparison of DPPH radical scavenging activity between control and S. crispa groups. $(--)$ : SMD of individual studies; $(\bullet)$ : summary SMDs of the comparison.

\subsection{Sensitivity Analysis}

Studies that used the same $S$. crispa extract, similar dosages and the same experimental objects were included in the sensitivity analysis. Wound healing rates in diabetes treatment and survival 
of cancer cells after anti-tumor activity were analyzed (Figures 12 and 13). All cases showed a high homogeneity and a high reduction of the percentages of cancer cells (SMD $=16.08(1.83,27.32), \mathrm{I}^{2}=0 \%$ ), as well as an improved wound healing ability of the objects (SMD $\left.=2.89(1.87,3.90), \mathrm{I}^{2}=13 \%\right)$ after treatment with S. crispa.

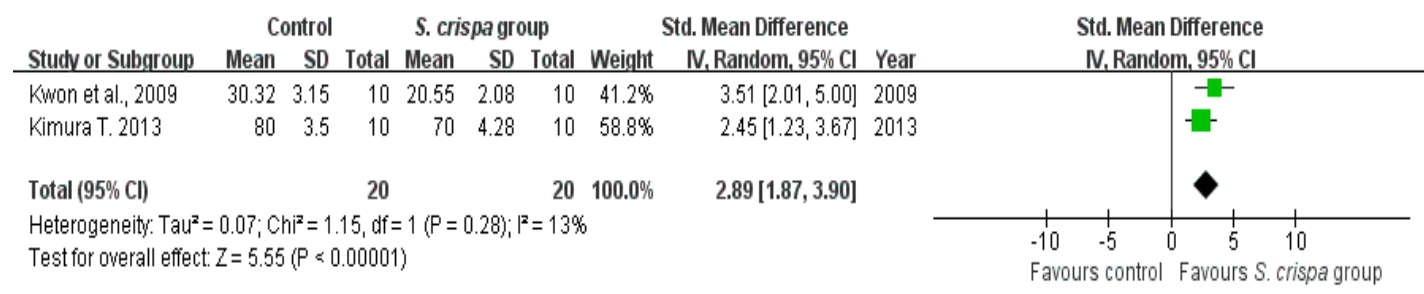

Figure 12. Sensitivity analysis of wound rates in diabetes treatment between control and S. crispa groups. (- - ): S MD of individual studies; $(\bullet)$ : summary SMDs of the comparison.

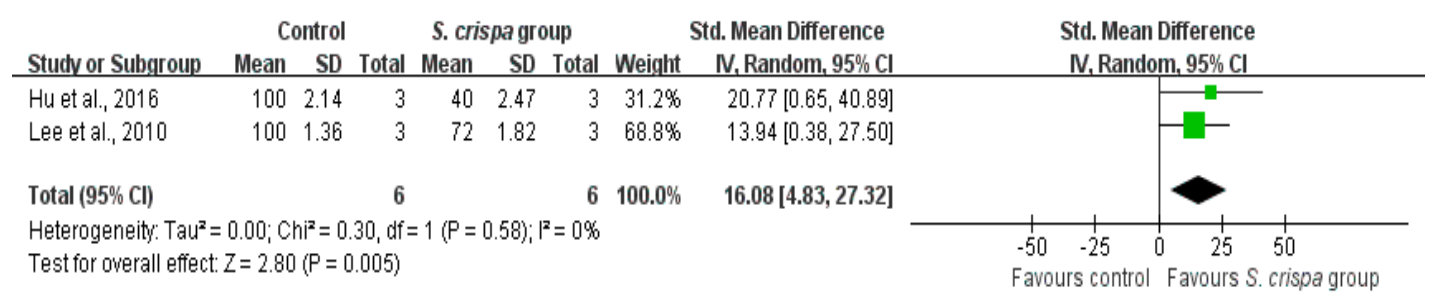

Figure 13. Sensitivity analysis of survival of cancer cell in cancer treatment between control and S. crispa groups. (-) $(-)$ SMD of individual studies; $(\bullet)$ : summary SMDs of the comparison.

\subsection{Bias Analysis}

Funnel plots were drawn to assess the publication bias of studies on the medical applications of S. crispa. Figures 14 and 15 are approximately symmetrical but small studies showing diabetes and cancer treatment effects of S. crispa remain unpublished. In contrast, Figure 16 estimated that the most important studies on anti-inflammatory activity of $S$. crispa have been missing, so the outcomes of the anti-inflammatory treatment were not highly significant statistically. Even though the funnel plots in Figures 17 and 18 also demonstrated that many relevant studies have not been published yet, all the published data were statistically significant for the anti-fungal and antioxidant activity of S. crispa extracts.

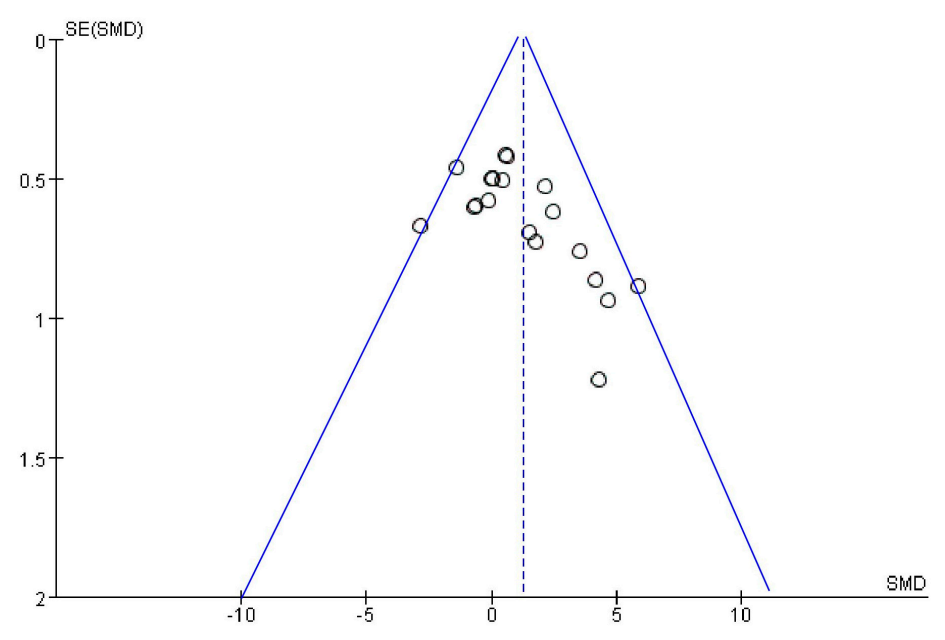

Figure 14. Funnel plot of studies evaluating diabetes treatment of S. crispa. 


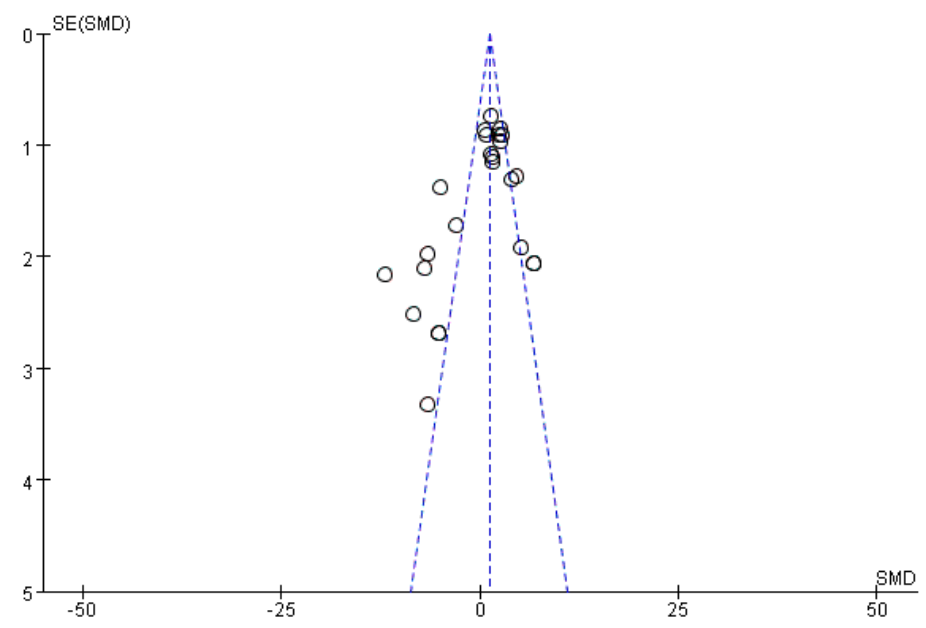

Figure 15. Funnel plot of studies assessment cancer treatment of S. crispa.

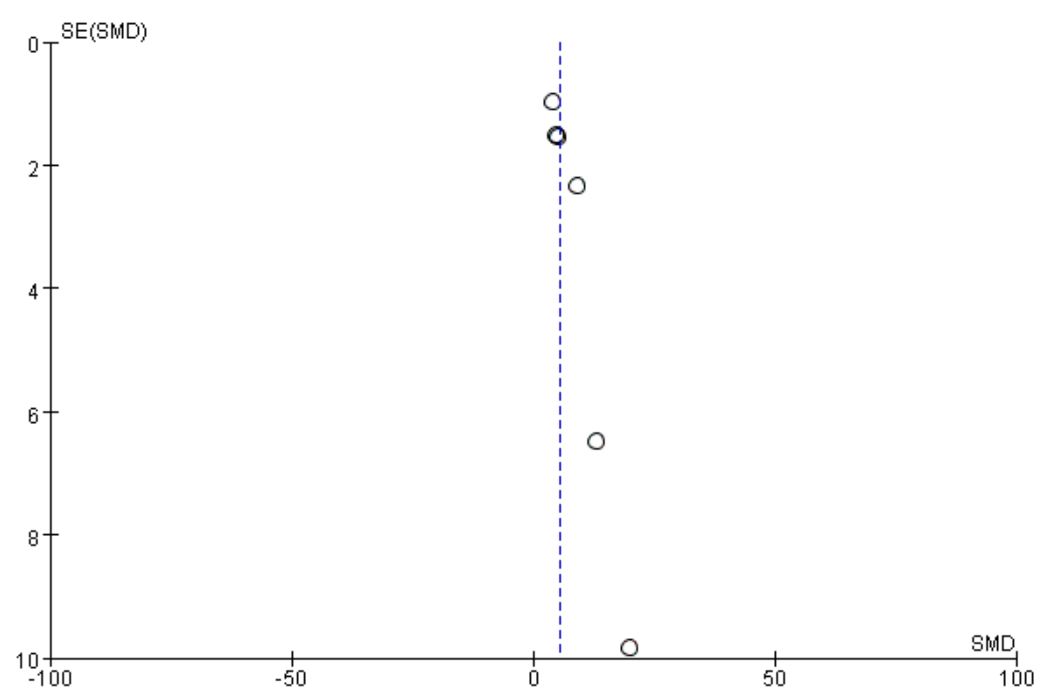

Figure 16. Funnel plot of studies assessment anti-inflammatory activity of S. crispa.

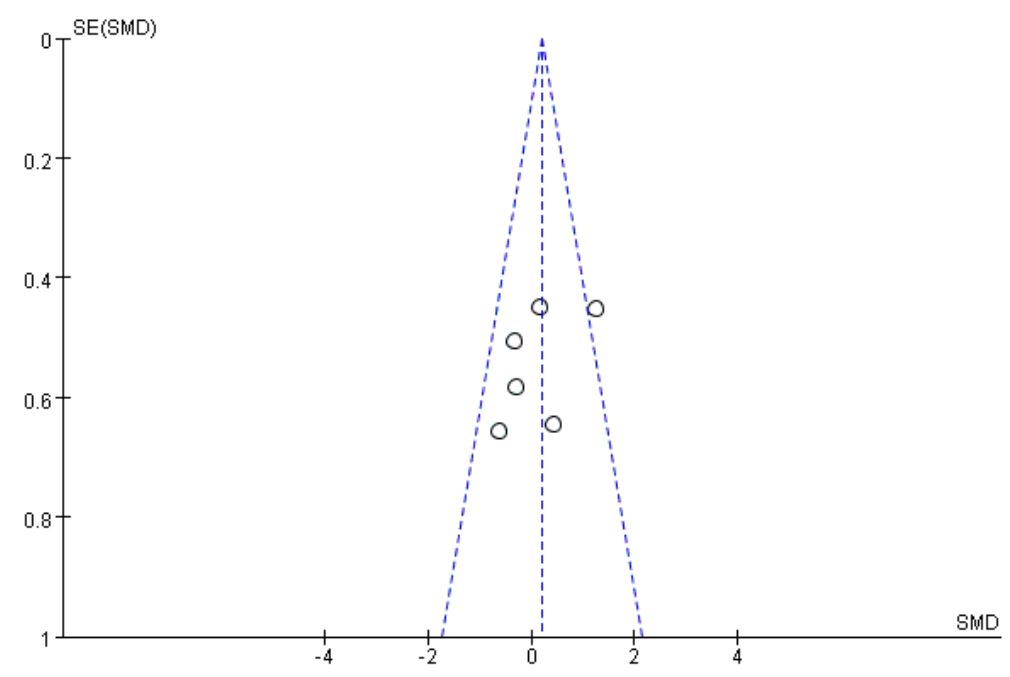

Figure 17. Funnel plot of studies evaluating the anti-fungal activity of S. crispa. 


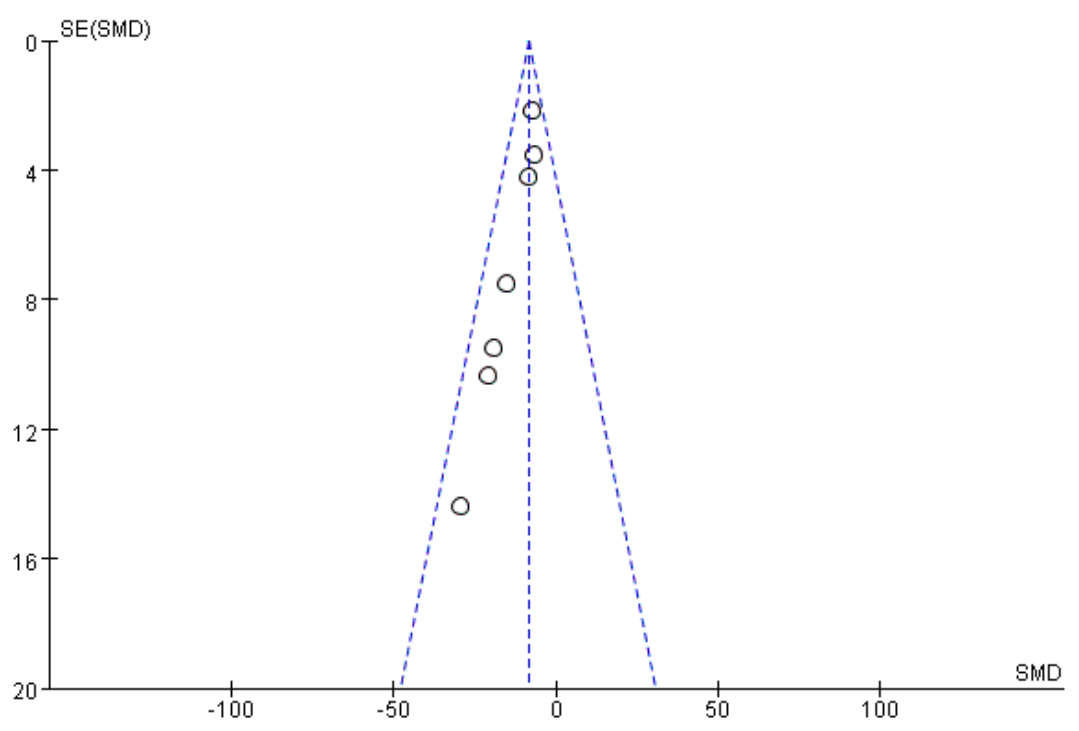

Figure 18. Funnel plot of studies evaluating antioxidant activity of S. crispa.

\section{Discussion}

In this systematic review and meta-analysis of thirty-three studies on the medical application of S. crispa extracts were confirmed that $S$. crispa is not only an edible mushroom but also a medicinal mushroom that has been increasingly cultivated because of its potential value in traditional medicine. Indeed, S. crispa contains highly physiological active substances (e.g., $\beta$-glucan, phenolic compounds, chloroform extract, and some antibiotic compounds) that can support a healthy level of blood-sugar and recovery of the normal cellular immunization [3]. The beneficial effects have been demonstrated by anti-diabetic, anti-tumor, anti-inflammatory, anti-fungal, and anti-oxidant activities [1,3,11,20,47]; almost all of the typical therapeutic effects of $S$. crispa showed significant differences, relative to the control groups.

As an immunomodulating substance, $\beta$-glucan plays an important role in most healing modalities [48]. Mainly, involving an enhance of the immune response against cancer and stimulating the cells of the innate immune system [48-51]. The discovery of specific receptors for glucans in cells, as well as interactions with other receptors mainly expressed by innate immune cells, have been reported as the primary mechanism of $\beta$-glucan for regulation of anti-tumor therapy and some associated medical treatments [51]. Our meta-analysis indicated that $S$. crispa extracts had a large influence in reducing significantly cancer cells viability and tumor cells suppression (Figures 4 and 5). Although, here there was not a high homogeneity in the IFN- $\gamma$ production aspect (Figure 6). Moreover, the estimate as clinical evidence for a relationship between structure and activity, suggested the contributions of multiple receptor-ligand interactions in glycan-mediated immunopotentiation.

Diabetes that has been caused by a single high dose of streptozotocin is typically accompanied by symptoms such as weight loss, polyuria, hyperglycemia, and neuroendocrine dysfunction $[6,14]$. On the other hand, whereas wound healing progresses at an optimal rate in healthy individuals, patients with diabetes usually exhibit delayed or impaired wound healing, which is a serious high-blood-glucose-related clinical problem [52]. The present subgroup analysis did not report any significant difference $\left(\mathrm{I}^{2}=91.9 \%\right.$ ) between S. crispa and control groups (Figure 3 and Table 3 ), suggesting that mushroom extracts have not had complete effects on all the diabetes symptoms. However, an individual analysis for each aspect, two topical therapy symptoms (incidence of wounds and serum insulin levels in the blood) were eliminated after treatment with S. crispa. In summary, S. crispa showed a slightly beneficial influence on diabetes therapeutics. Meanwhile, we expect that additional studies on S. crispa treatments will improve the accuracy of the analysis. 
Additionally, the mushroom has shown an anti-inflammatory activity $[1,2,47]$. The present analysis estimates (Figures 7 and 8, and Table 3) that studies on anti-inflammatory therapy were statistically significant, achieving a small homogeneity in the analysis. Furthermore, results also demonstrated that $S$. crispa extracts played an inhibitory role in inflammatory responses via regulation of NO production; suggesting a potential role as a component of inflammatory drugs.

Recently, some evidence has suggested that the biological actions of phenolic compounds are associated with their antioxidant capacity based on their ability to chelate metals and lipoxygenase inhibitors $[19,26]$. The present survey also considered and evaluated antioxidant activities of the medical mushroom by meta-analysis (Figures 10 and 11). According to the coefficient of heterogeneities of the analysis $\left(\mathrm{I}^{2}=0 \%\right.$ and $\left.10 \%\right)$, it was confirmed that phenolic compounds and other S. crispa extracts could significantly contribute to antioxidant properties; explaining the relationship between phenolic compounds and antioxidant activities, as well as anti-fungal ability.

Finally, anti-bacterial and anti-fungal compounds have been identified in S. crispa [43], though their utilities were reported in only three studies $[19,29,43]$. The analysis showed that after exposure to S. crispa extracts the numbers of bacteria and fungi were reduced, indicating that the mushroom, as a component of pharmaceuticals, can protect humans from bacterial and fungal contamination.

\section{Materials and Methods}

\subsection{Methods}

The study followed the Cochrane Collaboration method [46], as well as the Preferred Reporting Items for Systematic Reviews and Meta-Analyses (PRISMA) guidelines [53] to report a systematic review and meta-analysis. Also, this work was based on the protocols and reviews on medical applications of S. crispa. It included all the researches that assessed the ability of S. crispa extracts on human health treatment (i.e., diabetes and cancer treatment, anti-fungal, antioxidant, and anti-inflammatory activity). It excluded ineligible studies such as studies of the effects of mushroom in other application fields and contained inappropriate data for the analysis. It compared and analyzed the statistical significance of individual studies of the same effect of S. crispa for the specific therapeutics using meta-analysis. Outcomes provided an overview and a systematic assessment about the clinical efficacies of S. crispa based on comparing SMDs between control and S. crispa groups, as well as the heterogeneity coefficient $\left(\mathrm{I}^{2}\right)$ of each analysis [54].

\subsection{Literature Search and Data Extraction}

\subsubsection{Database Research Strategy}

The searched literature on medical applications of $S$. crispa extracts was performed in the databases PubMed (National Library of Medicine, Bethesda, MD, USA), EMBASE (Excerpta Medica database, Amsterdam, Netherlands), Elsevier (Information and Analytics, Amsterdam, Netherlands), CENTRAL (Cochrane Central Register of Controlled Trials, New York, NY, USA), and Web of Science (Institute of Scientific Information and Clarivate Analytics, Philadelphia, PA, USA), considering articles published between 1990 and 2018. Also, we made a hand searching for important conference papers, as well as checking reference lists. Combinations of the following keywords were used: S. crispa, Sparassis Latifolia, Cauliflower mushroom, Hanaratake, medical applications, immune stimulating activity, anti-tumor, anti-cancer, anti-microbial, anti-melanin, anti-metastatic, anti-inflammatory, anti-fungal, antioxidant, anti-viral, anti-diabetic, and anti-hypertensive activity. The respective reference lists of the identified papers also were searched. All articles were written in English, Korean or Japanese.

\subsubsection{Data Extraction}

The bibliographic reference list was screened and manually selected from eligible studies from the electronic database for the meta-analysis, according to the criteria of associations between medical 
applications of S. crispa and human therapeutics. The following information from each article was obtained: article title, the name of first author, location, study year, publication year, study design, number of participants, dosage and administration, type of treatment and outcomes. These items were selected based on the presence and short descriptions of important study characteristics (e.g., title, abstract, study design, experimental object, and kind of medical application). The criteria included in the quantitative meta-analysis were empirical data that could be used to calculate the SMDs of treatments.

\subsubsection{Exclusion Criteria}

Articles were excluded based on the following criteria: no data presentation (e.g., review articles and editorials), incomplete data, repeated and similar studies.

\subsection{Meta-Analysis}

For each analysis, we determined the effect size (SMD) and 95\% CI for the comparison between control and S. crispa groups. The SMD was obtained by dividing the mean difference between the two groups by the pooled variance, with adjustment for small samples. We considered SMDs about 0.2 or less as small values, 0.5 as moderate values, and 0.8 or greater values as large [54]. We quantified the extension to which the observed variability between studies was due to true differences between studies using the $\mathrm{I}^{2}$ statistic. Heterogeneity was considered to be small when $\mathrm{I}^{2}$ was less than $25 \%$, moderate when $25-50 \%$, and large when greater than $50 \%$ [54]. The subgroup analysis assessed the overall effects in the subgroups according to the model type, kind(s) of treatment(s), and symptoms. The value of $p<0.05$ was considered statistically significant, and bias was examined using a funnel plot.

All these analyses were performed using Review Manager [46] (version 5.3, Copenhagen: The Nordic Cochrane Centre, The Cochrane Collaboration, 2014).

\section{Limitation of Study}

The limitation of this study is the number of individual studies, which are not as large as our expectation in some respect (i.e., anti-inflammatory, anti-fungal, and antioxidant activity) leading to estimations not highly significant. Especially in the sensitivity assessment, the results might be not high accuracy because of a very small quantity of those that have the same test conditions for consideration of the sensitivity.

\section{Conclusions}

Briefly, this investigation determined that S. crispa is useful in medical therapeutics, each extract showed their properties and specific applications. Particularly, a meta-analysis revealed that $\beta$-glucan, which is known as the primary ingredient of $S$. crispa extract, plays an important part in the treatment of cancer and diabetes. Additionally, the analysis confirmed that $\beta$-glucan and other constituents (i.e., phthalide compounds, low-molecular-weight ingredients, and anti-bacterial substances) are used in anti-inflammatory activities, as well as antioxidant and anti-fungal immunotherapies. However, recent studies have focused on the clinical application of $S$. crispa $[3,12,13,26,31,35,44]$. To support our analysis, further studies to improve the statistical significance is necessary.

Author Contributions: Y.-C.L. planned the study and contributed the main ideas; L.T.N.N. collected the data and L.T.N.N. and Y.-C.L. were principally responsible for the writing of the manuscript; Y.-C.L., Y.-K.O., and Y.-J.L. commented on and revised the manuscript.

Acknowledgments: This work was supported by the Korean Ministry of Environment's “GAIA project (2015000550006)" and by the Basic Science Research Program through the National Research Foundation of Korea funded by the Ministry of Education (NRF-2017R1D1A1A09000642).

Conflicts of Interest: The authors declare that they have no competing interests. 


\section{Abbreviations}

S. crispa Sparassis crispa

SMD Standardized mean difference

\section{References}

1. Elsayed, E.A.; El Enshasy, H.; Wadaan, M.A.; Aziz, R. Mushrooms: A potential natural source of anti-inflammatory compounds for medical applications. Mediat. Inflamm. 2014, 2014, 805841. [CrossRef] [PubMed]

2. Molitoris, H.P. Mushroom in medicine. Folia Microbiol. 1994, 39, 91-98. [CrossRef]

3. Kimura, T. Natural products and biological activity of the pharmacologically active Cauliflower mushroom Sparassis crispa. BioMed Res. Int. 2013, 2013, 156-167. [CrossRef] [PubMed]

4. Sou, H.D.; Ryoo, R.; Ryu, S.R.; Ka, K.H.; Park, H.; Joo, S.H. Morphological and genetic characteristics of newly crossbred Cauliflower mushroom (Sparassis latifolia). J. Microbiol. 2013, 51, 552-557. [CrossRef] [PubMed]

5. Kawagishi, H.; Hayashi, K.; Tokuyama, S.; Hashimoto, N.; Kimura, T.; Dombo, M. Novel bioactive compound from the Sparassis crispa mushroom. Biosci. Biotechnol. Biochem. 2007, 71, 1804-1806. [CrossRef] [PubMed]

6. Kwon, A.H.; Qiu, Z.; Hashimoto, M.; Yamamoto, K.; Kimura, T. Effects of medicinal mushroom (Sparassis crispa) on wound healing in streptozotocin-induced diabetic rats. Am. J. Surg. 2009, 197, 503-509. [CrossRef] [PubMed]

7. Yoshikawa, K.; Kokudo, N.; Hashimoto, T.; Yamamoto, K.; Inose, T.; Kimura, T. Novel phthalide compounds from Sparassis crispa (Hanabiratake), Hanabiratakelide A-C, exhibiting anti-cancer related activity. Biol. Pharm. Bull. 2010, 33, 1355-1359. [CrossRef] [PubMed]

8. Kim, M.-Y.; Seguin, P.; Ahn, J.-K.; Kim, J.-J.; Chun, S.-C.; Kim, E.-H.; Seo, S.-H.; Kang, E.-Y.; Kim, S.-L.; Park, Y.-J.; et al. Phenolic compound concentration and antioxidant activities of edible and medicinal mushrooms from Korea. J. Agric. Food Chem. 2008, 56, 7265-7270. [CrossRef] [PubMed]

9. Lee, Y.-G.; Thi, N.N.; Kim, H.-G.; Lee, D.Y.; Lee, S.-E.; Kim, G.-S.; Baek, N.-I. Ergosterol peroxides from the fruit body of Sparassis crispa. Appl. Biol. Chem. 2016, 59, 313-316. [CrossRef]

10. Yang, Y.H.; Kang, H.W.; Ro, H.S. Cloning and molecular characterization of $\beta$-1,3-glucan synthase from Sparassis crispa. Mycobiology 2014, 42, 167-173. [CrossRef] [PubMed]

11. Petrova, R.D.; Reznick, A.Z.; Wasser, S.P.; Denchev, C.M.; Nevo, E.; Mahajna, J. Fungal metabolites modulating NF-kB activity: An approach to cancer therapy and chemoprevention (review). Oncol. Rep. 2008, 19, 299-308. [CrossRef] [PubMed]

12. Yamamoto, K.; Kimura, T. Orally and topically administered Sparassis crispa (Hanabiratake) improved healing of skin wounds in mice with streptozotocin-induced diabetes. Biosci. Biotechnol. Biochem. 2014, 77, 1303-1305. [CrossRef] [PubMed]

13. Ohno, N.; Miura, N.N.; Nakajima, M.; Yadomae, T. Antitumor 1,3- $\beta$-glucan from cultured fruit body of Sparassis crispa. Biol. Pharm. Bull. 2000, 23, 866-872. [CrossRef] [PubMed]

14. Yamamoto, K.; Kimura, T. Dietary Sparassis crispa (Hanabiratake) ameliorates plasma levels of adiponectin and glucose in type 2 diabetic mice. J. Health Sci. 2010, 56, 541-546. [CrossRef]

15. Harada, T.; Miura, N.; Adachi, Y.; Nakajima, M.; Yadomae, T.; Ohno, N. Effect of SCG, 1,3- $\beta$-D-glucan from Sparassis crispa on the hematopoietic response in cyclophosphamide induced leukopenic mice. Biol. Pharm. Bull. 2002, 25, 931-938. [CrossRef] [PubMed]

16. Joshi, M.; Sagar, A. In vitro free radical scavenging activity of a wild edible mushroom, Sparassis crispa (Wulf.) Fr., from North Western Himalayas, India. J. Mycol. 2014, 2014, 748531. [CrossRef]

17. Bang, S.; Chae, H.S.; Lee, C.; Choi, H.G.; Ryu, J.; Li, W.; Lee, H.; Jeong, G.S.; Chin, Y.W.; Shim, S.H. New aromatic compounds from the fruiting body of Sparassis crispa (Wulf.) and their inhibitory activities on proprotein convertase subtilisin/kexin type 9 mRNA expression. J. Agric. Food Chem. 2017, 65, 6152-6157. [CrossRef] [PubMed]

18. Katarzyna, S.-Z.; Bozena, M.; Agnieszka, S. Antioxidant components of selected indigenous edible mushrooms of the obsolete order aphyllophorales. Rev. Iberoam. Micol. 2015, 32, 99-102. [CrossRef]

19. Lee, E.J.; Kim, J.-E.; Park, M.-J.; Park, D.-C.; Lee, S.-P. Antimicrobial effect of the submerged culture of Sparassis crispa in soybean curd whey. Korean J. Food Preserv. 2013, 20, 111-120. [CrossRef] 
20. Ohno, N.; Harada, T.; Masuzawa, S.; Miura, N.N.; Adachi, Y.; Nakajima, M.; Yadomawe, T. Antitumor activity and hematopooietic response of a $\beta$-glucan extracted from the mushroom Sparassis crispa (Wulf) Fr. Int. J. Med. Mushrooms 2001, 3, 193-198. [CrossRef]

21. Yamamoto, K.; Nishikawa, Y.; Kimura, T.; Dombo, M.; Matsuura, N.; Sugitachi, A. Antitumor activities of low molecular weight fraction derived from the cultured fruit body of Sparassis crispa in tumor-bearing mice. Nippon Shok. Kag. Kog. Kaishi 2007, 54, 419-423. [CrossRef]

22. Choi, W.-S.; Shin, P.-G.; Bok, Y.Y.; Jun, N.H.; Kim, G.-D. Anti-inflammatory effects of Sparassis crispa extracts. J. Mushroom 2013, 11, 46-51. [CrossRef]

23. Choi, M.-H.; Han, H.-K.; Lee, Y.-J.; Jo, H.-G.; Shin, H.-J. In vitro anti-cancer activity of hydrophobic fractions of Sparassis latifolia extract using AGS, A529, and HepG2 cell lines. J. Mushroom 2014, 12, 304-310. [CrossRef]

24. Kim, I.-K.; Yun, Y.C.; Shin, Y.C.; Yoo, J. Effect of Sparassis crispa extracts on immune cell activation and tumor growth inhibition. J. Life Sci. 2013, 23, 984-988. [CrossRef]

25. Lee, J.-J.; Son, H.-Y.; Choi, Y.-M.; Cho, J.-H.; Min, J.-K.; Oh, H.-K. Physicochemical components and antioxidant activity of Sparassis crispa mixture fermented by lactic acid bacteria. Korean J. Food Preserv. 2016, 23, 361-368. [CrossRef]

26. Park, S.-E.; Seo, S.-H.; Moon, Y.-S.; Lee, Y.-M.; Na, C.-S.; Son, H.-S. Antioxidant and immunological activities of Sparassis crispa fermented with Meyerozyma guilliermondii FM. J. Korean Soc. Food Sci. Nutr. 2016, 45, 1398-1405. [CrossRef]

27. Lee, D.-S.; Kim, K.-H.; Yook, H.-S. Antioxidant activities of different parts of Sparassis crispa depending on extraction temperature. J. Korean Soc. Food Sci. Nutr. 2016, 45, 1617-1622. [CrossRef]

28. Yamamoto, K.; Kimura, T.; Sugitachi, A.; Matsuurac, N. Anti-angiogenic and anti-metastatic effects of 3-1,3-D-glucan purified from Hanabiratake, Sparassis crispa. Biol. Pharm. Bull. 2009, 32, 259-263. [CrossRef] [PubMed]

29. Jeong, S.Y.; Kang, S.; Hua, C.S.; Ting, Z.; Park, S. Synbiotic effects of $\beta$-glucans from Cauliflower mushroom and Lactobacillus fermentum on metabolic changes and gut microbiome in estrogen-deficient rats. Genes Nutr. 2017, 12, 31. [CrossRef] [PubMed]

30. Takashi, K. Antitumor Effects and Their Related Components of Sparassis crispa and Other Pharmacological Aspect of Sparassis crispa; Kyoto University: Kyoto, Japan, 2013; p. 96.

31. Yoshitomi, H.; Iwaoka, E.; Kubo, M.; Shibata, M.; Gao, M. Beneficial effect of Sparassis crispa on stroke through activation of Akt/eNOS pathway in brain of SHRSP. J. Nat. Med. 2011, 65, 135-141. [CrossRef] [PubMed]

32. Kim, H.S.; Kim, J.Y.; Ryu, H.S.; Park, H.G.; Kim, Y.O.; Kang, J.S.; Kim, H.M.; Hong, J.T.; Kim, Y.; Han, S.B. Induction of dendritic cell maturation by $\beta$-glucan isolated from Sparassis crispa. Int. Immunopharmacol. 2010, 10, 1284-1294. [CrossRef] [PubMed]

33. Lee, S.Y.; Lee, Y.G.; Byeon, S.E.; Han, S.; Choi, S.S.; Kim, A.R.; Lee, J.; Lee, S.J.; Hong, S.; Cho, J.Y. Mitogen activated protein kinases are prime signalling enzymes in nitric oxide production induced by soluble $\beta$-glucan from Sparassis crispa. Arch. Pharm. Res. 2010, 33, 1753-1760. [CrossRef] [PubMed]

34. Choi, J.H.; Lee, H.J.; Kim, S. Purification and antithrombotic activity of wulfase, a fibrinolytic enzyme from the fruit bodies of the edible and medicinal mushroom Sparassis crispa Wulf. Ex. Fr. Appl. Biochem. Microbiol. 2016, 52, 608-614. [CrossRef]

35. Harada, T.; Nagimura, N.; Adachi, Y.; Nakajima, M.; Ohno, T.Y.N. Antibody to soluble 1,3/1,6- $\beta$-D-glucan, SCG in sera of naive DBA/2 mice. Biol. Pharm. Bull. 2003, 26, 1225-1228. [CrossRef] [PubMed]

36. Hu, S.; Wang, D.; Zhang, J.; Du, M.; Cheng, Y.; Liu, Y.; Zhang, N.; Wang, D.; Wu, Y. Mitochondria related pathway is essential for polysaccharides purified from Sparassis crispa mediated neuro-protection against glutamate-induced toxicity in differentiated PC12 cells. Int. J. Mol. Sci. 2016, 17, 133. [CrossRef] [PubMed]

37. Harada, T.; Miura, N.N.; Adachi, Y.; Nakajima, M.; Yadomae, T.; Ohno, N. IFN- $\gamma$ induction by SCG, 1,3- $\beta$-D-glucan from Sparassis crispa, in DBA/ 2 mice in vitro. J. Interferon Cytokine Res. 2002, 22, 1227-1239. [CrossRef] [PubMed]

38. Harada, T.; Miura, N.N.; Adachi, Y.; Nakajima, M.; Yadomae, T.; Ohno, N. Granulocyte-macrophage colony-stimulating factor (GM-CSF) regulates cytokine induction by $1,3-\beta-D-$ glucan SCG in DBA/ 2 mice in vitro. J. Interferon Cytokine Res. 2004, 24, 478-479. [CrossRef] [PubMed] 
39. Harada, T.; Nagimura, N.; Adachi, Y.; Nakajima, M.; Ohno, T.Y.N. Mechanism of enhanced hematopoietic response by soluble $\beta$-glucan SCG in cyclophosphamide-treated mice. Microbiol. Immunol. 2006, 50, 687-690. [CrossRef] [PubMed]

40. Nameda, S.; Harada, T.; Miura, N.N.; Adachi, Y.; Yadomae, T.; Nakajima, M.; Ohno, N. Enhanced cytokine synthesis of leukocytes by a $\beta$-glucan preparation, SCG, extracted from a medicinal mushroom, Sparassis crispa. Immunopharmacol. Immunotoxicol. 2003, 25, 321-335. [CrossRef] [PubMed]

41. Yao, M.; Yamamoto, K.; Kimura, T.; Dombo, M. Effects of Hanabiratake (Sparassis crispa) on allergic rhinitis in ova-sensitized mice. Food Sci. Technol. Res. 2008, 14, 589-594. [CrossRef]

42. Kim, H.H.; Lee, S.; Singh, T.S.; Choi, J.K.; Shin, T.Y.; Kim, S.H. Sparassis crispa suppresses mast cell-mediated allergic inflammation: Role of calcium, mitogen-activated protein kinase and nuclear factor-kB. Int. J. Mol. Med. 2012, 30, 344-350. [CrossRef] [PubMed]

43. Woodward, S.; Sultan, H.Y.; Barrett, D.K.; Pearce, R.B. Two new antifungal metabolites produced and in decayed trees. J. Gen. Appl. Microbiol. 1992, 139, 153-159. [CrossRef]

44. Puttaraju, N.G.; Venkateshaiah, S.U.; Dharmesh, S.M.; Urs, S.M.N.; Somasundaram, R. Antioxidant activity of indigenous edible mushrooms. J. Agric. Food Chem. 2006, 54, 9764-9772. [CrossRef] [PubMed]

45. Lee, M.R.; Hou, J.G.; Begum, S.; Xue, J.J.; Wang, Y.B.; Sung, C.K. Comparison of constituents, antioxidant potency, and acetylcholinesterase inhibition in Lentinus edodes, Sparassis crispa, and Mycoleptodonoides aitchisonii. Food Sci. Biotechnol. 2013, 22, 1747-1751. [CrossRef]

46. Higgins, J.P.; Altman, D.G. The Cochrane Book Series; The Cochrane Collaboration: London, UK, 2008.

47. Lull, C.; Wichers, H.J.; Savelkoul, H.F. Antiinflammatory and immunomodulating properties of fungal metabolites. Mediat. Inflamm. 2005, 2005, 63-80. [CrossRef] [PubMed]

48. Novak, M.; Vetvicka, V. $\beta$-glucans, history, and the present: Immunomodulatory aspects and mechanisms of action. J. Immunotoxicol. 2008, 5, 47-57. [CrossRef] [PubMed]

49. Akramienè, D.; Kondrotas, A.; Didžiapetrienè, J.; Kèvelaitis, E. Effect of $\beta$-glucans on the immune system. Medicina 2007, 43, 597-606. [PubMed]

50. Vannucci, L.; Krizan, J.; Sima, P.; Stakheev, D.; Caja, F.; Rajsiglova, L.; Horak, V.; Saieh, M. Immunostimulatory properties and antitumor activities of glucans (review). Int. J. Oncol. 2013, 43, 357-364. [CrossRef] [PubMed]

51. Chan, G.C.; Chan, W.K.; Sze, D.M. The effects of $\beta$-glucan on human immune and cancer cells. J. Hematol. Oncol. 2009, 2, 25. [CrossRef] [PubMed]

52. Berdal, M. Wound Healing in Diabetes; Faculty of Health Sciences Metabolic and Renal Research Group: The Arctic University of Norway, Northern Norway, 2017; p. 73.

53. Liberati, A.; Altman, D.G.; Tetzlaff, J.; Mulrow, C.; Gotzsche, P.C.; Ioannidis, J.P.; Clarke, M.; Devereaux, P.J.; Kleijnen, J.; Moher, D. The PRISMA statement for reporting systematic reviews and meta-analyses of studies that evaluate health care interventions: Explanation and elaboration. PLoS Med. 2009, 6, e1000100. [CrossRef] [PubMed]

54. Myung, S.-K. Systematic Review and Meta-Analysis; National Cancer Center: Gyeonggi-do, Korea, $2015 ;$ p. 125. 